\title{
Clustering Consumers According to Their Environmental Concerns and Scepticisms
}

\author{
Tahir Albayrak, Meltem Caber and Şafak Aksoy
}

\begin{abstract}
In this study, authors aimed to measure the environmentally sensitive behaviour of consumers and to cluster them according to their environmental concerns and scepticisms. These two psychographic variables were selected by their diverse nature and importance for understanding the basic determinants of a continuously developing market segment. Since the studies about the role of scepticism on environmentally sensitive consumer behaviour are quite limited in marketing literature, this study is expected to contribute towards the efforts of filling the existing gap.
\end{abstract}

Index Terms-Environmental concern, scepticism, consumer behaviour

\section{INTRODUCTION}

In the last couple of decades, customer-centric approaches put the customers into the central point of the marketing management processes of companies. In the meantime, existing and emerging market segments became more sophisticated as well as divergent from each other. Depending on the characteristics of the target market segments, companies now have to be closer to their customers and try to learn new market trends from them. For example, environmentally sensitive consumers tend to concern about the environmental issues such as air pollution, global heating, re-cycling etc. more than other market segments do. Although environmentally sensitive consumers prefer to purchase environmentally friendly products, exaggerated advertisements and improper labelling by companies may generate scepticism among these customers. Therefore, the relationships between environmental concern, scepticism, and environmentally sensitive consumer behaviour require a deeper look for a better understanding of this growing market segment.

\section{II.ENVIRONMENTALLY SENSITIVE CONSUMER BEHAVIOUR}

Some companies target specifically those people who are environmentally sensitive and prefer to purchase "green" products. To identify these environmentally sensitive consumers and define meaningful market segments, mostly demographic characteristics of customers are used and analyzed. However, many studies have indicated that demographics are not the exact and only determinants of the environmental concern and environmentally sensitive behaviour (Mainieri et al., 1997; Schlegelmilch et al., 1996).

Therefore, psychographic variables began to be used as alternative determinants of the "green consumer market segment". These psychographic variables can be ranged as environmental concern, perceived consumer effectiveness, environmental knowledge, norms, liberalism, altruism, individualism and collectivism. In this study, scepticism, a new but widely ignored psychographic concept in the related literature, and environmental concern will be discussed and related to the environmentally sensitive consumer behaviour.

\section{ENVIRONMENTAL CONCERN}

Environmental concern is defined in various ways, because it is a very complicated and unstable concept (Chan and Lau, 2004). Crosby et al. (1981) define it as having a strong attitude for protecting the environment. The same authors re-define it later as a general attitude which has an indirect influence on attitude via behavioural intent (Gill et al., 1986). On the other hand, several studies exist which accept environmental concern synonymous with environmental attitude (Chan and Lau, 2004). Chan and Lau (2004) underline that Dunlap and Jones (2002) have offered one of the most inclusive definitions of the environmental concern. According to this definition, environmental concern is the awareness of a person about the environmental problems, his or her support attempts for solving them or the level of his or her willingness for contributing such attempts. Kim and Choi (2005) point out that it is much more possible for people who are highly concerned about the environmental problems than the others to purchase products for their environmental characteristics. Many studies are based on the supposition which admits that the level of a person's environmental concern has a direct and strong influence on recycling, energy saving, environmentally friendly product purchase or travel type selections (Bamberg, 2003).

\section{SCEPTICISM}

Scepticism is a cognitive reaction which varies according to the occasion and content of the communication (Mohr et al., 1998). Scepticism does not mean a general mood, but usually occurs in some circumstances. A sceptic person doubts about other people's expressions or attitudes, however he or she can be persuaded if some evidences are presented. Consumers usually consider the environmental claims as exaggerated or profiteer, which mislead themselves when they try to make a correct decision. Especially exaggerated claims attract society's or concerned people's attention by theoretically correct but practically incorrect claims (Ellen et al., 1991). In the marketing literature, scepticism is generally examined by advertisement-related studies. Scepticism for the advertisements may be identified as the tendency of disbelief the consumers hold towards the 
claims (Obermiller and Spangenberg, 1998). The effectiveness of the advertisements are negatively affected by scepticism, and sceptic consumers tend to ignore advertisements which disconnect the link between the advertisement and the purchase intent (Obermeiller et al., 2005).

\section{V.MeTHODOLOGY}

The aim of this research is to understand why some consumers behave in a dissimilar way to environmentally sensitive claims and statements. Researchers can group consumers into "true" and "false" environmentalists as well as other types in the global marketplace, and isolate distinct market segments. If companies clarify different market segments' characteristics, they can offer the right mix of products or services to the right market segments which in turn improve their profitability and efficiency. In addition, market segmentation helps to increase customer satisfaction and expectation-perception coherence (Martin et al., 2000). In accordance with the research aims, the present authors conducted a survey among the graduate students of Akdeniz
University, Turkey, in the period of September-November 2008. Previous studies about the green purchase behaviour showed that university students can reflect the (general) consumer approaches in the market. Although the extent to which student subjects represent the general population can be debated (e.g., Gordon et al., 1987), using university students as subjects has been a research method practised worldwide for many years, mainly for their accessibility by the researcher and homogeneity as a group (Calder et al., 1981). The research survey consisted of three sections; in the first section demographic questions were asked to the participants. In the second section, environmental concerns of the participants were measured through 13 questions obtained from Stein and Dietz (1994). In the last section, scepticism of the participants towards environmental claims was evaluated by 13 questions which were obtained from Mohr et al. (1998). Each latent construct was measured by a 5 point Likert scale. The proportion of males in the sample was $57,6 \%$, and the average age was 22,2 . The average monthly incomes of the majority of the $(51,3 \%)$ participants were between 500 - 1000 \$ (Table 1).

\begin{tabular}{llcc}
\multicolumn{4}{c}{ TABLE 1: Demographics OF THE PARTICIPANTS } \\
\hline \\
Gender & Total & $\begin{array}{c}\text { Percentage } \\
(\%)\end{array}$ \\
\hline Age & Male & 110 & 57,6 \\
\hline Monthly Income & Female & 81 & 42,4 \\
& Mean & 22,19 & \\
& Less than $500 \$$ & 44 & 23,3 \\
& $500-1000 \$$ & 97 & 51,3 \\
& $1001-1500 \$$ & 28 & 14,8 \\
& More than $1500 \$$ & 22 & 10,6 \\
\hline
\end{tabular}

Item quality and scale reliability were assessed with item-total correlations, standard deviations, item range of responses, and coefficient alpha. Items which have item-total correlations below .50 were deleted. The full range of responses was again used for all items. Coefficient alpha estimates were .774 for environmental concern and .773 for scepticism. These results provided strong evidence for the internal consistency of the scales. After the analyses, six items for environmental concern and five items for scepticism have remained (Table 2).

TABLE 2: MEANS AND STANDARD DEVIATIONS OF THE ITEMS

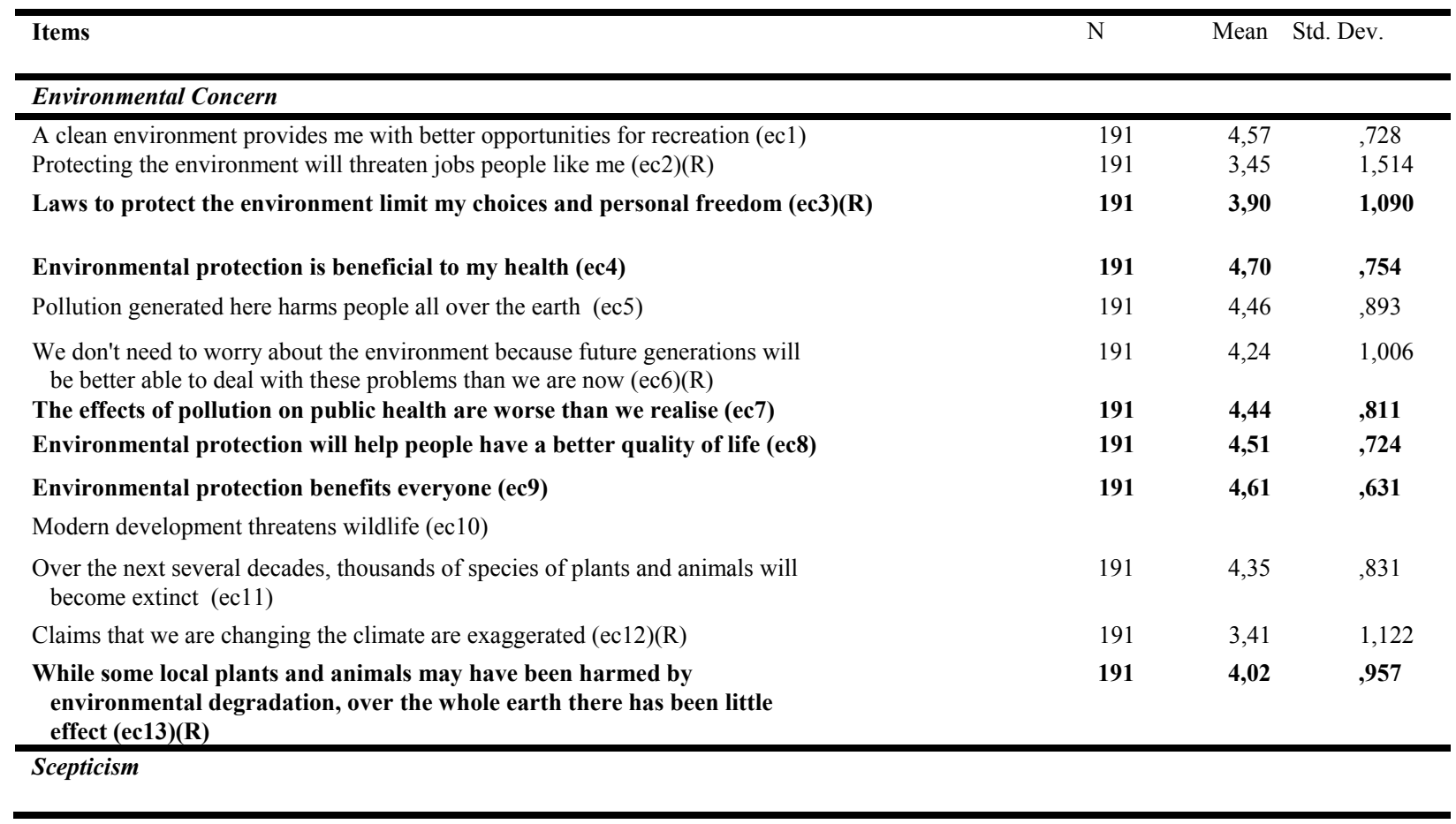




\begin{tabular}{|c|c|c|c|}
\hline $\begin{array}{l}\text { Most environmental claims made on package labels or in advertising are true } \\
\text { (scep1) }\end{array}$ & 191 & 2,80 & ,932 \\
\hline $\begin{array}{l}\text { I am sceptical about the accuracy of environmental claims made on } \\
\text { package labels or in advertising (scep2) }\end{array}$ & 191 & 3,54 & ,955 \\
\hline $\begin{array}{l}\text { Most environmental claims on package labels or in advertising } \\
\text { provide consumers with useful information for making choices (scep3) }\end{array}$ & 191 & 2,65 & ,932 \\
\hline $\begin{array}{l}\text { Because environmental claims are exaggerated, consumers would be better off } \\
\text { if such claims on package labels or in advertising were eliminated (scep4) }\end{array}$ & 191 & 3,18 & 1,043 \\
\hline The only environmental claims I believe are the ones that I can verify (scep5) & 191 & 3,79 & ,983 \\
\hline $\begin{array}{l}\text { Most environmental claims on package labels or in advertising are } \\
\text { intended to mislead rather than to inform consumers (scep6) }\end{array}$ & 191 & 2,98 & 1,005 \\
\hline $\begin{array}{l}\text { I don't believe environmental claims on package labels or in advertising until } \\
\text { the manufacturers provide evidence that claims are true (scep7) }\end{array}$ & 191 & 3,52 & ,934 \\
\hline $\begin{array}{l}\text { Environmental claims on package labels or in advertising lead people to } \\
\text { believe things that aren't true (scep8) }\end{array}$ & 191 & 3,25 & 1,030 \\
\hline $\begin{array}{l}\text { I do not believe most environmental claims made on package labels or in } \\
\text { advertising (scep9) }\end{array}$ & 191 & 2,90 & ,989 \\
\hline $\begin{array}{l}\text { Environmental claims made on package labels or in advertisements are } \\
\text { generally truthful (scep10) }\end{array}$ & 191 & 2,87 & ,923 \\
\hline $\begin{array}{l}\text { Environmental claims on package labels or in advertising should be more } \\
\text { closely regulated (scep11) }\end{array}$ & 191 & 4,23 & ,786 \\
\hline Most businesses shirk their responsibility to the consumer (scep12) & 191 & 3,64 & ,990 \\
\hline $\begin{array}{l}\text { Most businesses are more interested in making profits than in serving } \\
\text { consumers (scep13) }\end{array}$ & 191 & 4,26 & ,913 \\
\hline
\end{tabular}

For understanding the influence of scepticism on green purchase behaviour, linear regression analysis was used. Here, the dependent variable was the behaviour and measured by "When I have a choice between two equal products, I purchase the one less harmful to other people and the environment". The results of the analysis showed that environmental concern had a positive and statistically significant influence on green purchase behaviour. However, scepticism had a negative but statistically insignificant influence on the behaviour (Table 3).

TABLE 3: REGRESSION ANALYSIS RESULTS

\begin{tabular}{|c|c|c|c|c|c|c|}
\hline \multirow[b]{2}{*}{ Model } & & \multicolumn{2}{|c|}{ Unstandardized Coefficients } & \multirow{2}{*}{$\begin{array}{c}\begin{array}{c}\text { Standardized } \\
\text { Coefficients }\end{array} \\
\text { Beta }\end{array}$} & \multirow[b]{2}{*}{$\mathrm{t}$} & \multirow[b]{2}{*}{ Sig. } \\
\hline & & B & Std. Error & & & \\
\hline & (Constant) & 1,726 &, 717 & & 2,408 &, 017 \\
\hline & Env. Concern &, 561 &, 137 &, 287 & 4,096 &, 000 \\
\hline & Scepticism &,- 041 &, 111 &,- 026 &,- 373 & ,710 \\
\hline
\end{tabular}

Dependent Variable: When I have a choice between two equal products, I purchase the one less harmful to other people and the environment

The next step was to cluster the participants according to their environmental concerns and scepticisms. The means of each dimension were calculated and Hierarchical Clustering Analysis (Ward Method) was used for clustering. A solution of three clusters was obtained for the participants which were named as; keen sceptics, fanatics, and hesitants (Table 4).

TABLE 4: CLUSTER ANALySIS RESUltS

\begin{tabular}{llcc}
\hline & & Environmental concern & Scepticism \\
\hline Keen Sceptics & mean & 4,63 & 3,60 \\
& $\mathrm{~N}$ & 81 & 81 \\
& std.dev. &, 308 &, 489 \\
\hline Fanatics & mean & 4,56 & 2,34 \\
& N & 61 & 61 \\
& std.dev. &, 330 &, 414 \\
\hline
\end{tabular}




\begin{tabular}{llcc}
\hline Hesitants & mean & 3,65 & 3,22 \\
& & & 49 \\
& N & 49 &, 463 \\
\hline std.dev. &, 575 & 132.73 \\
Sig. in 0.01 & F & 103,35 & $.000^{*}$ \\
\hline
\end{tabular}

Keen sceptics are those people who have a high level of environmental concern, together with a high level of scepticism. They are very keen on environmental issues but very sceptic about the environmental claims which negatively influence their green purchase behaviour. Fanatics are both environmentally concerned and optimistic about the environmental claims. Hesitants have a moderate level of environmental concern and scepticism; They are expected to behave neither environmentally sensitive nor purchase green products.

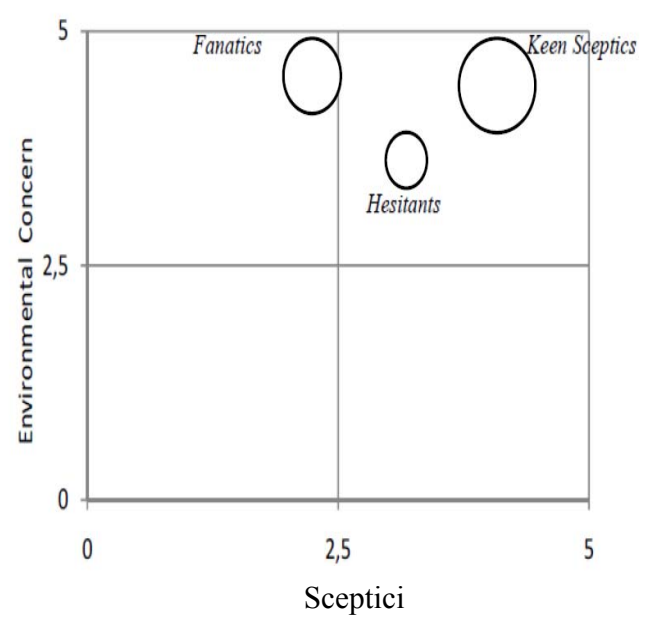

Figure 1: Customer Segments and Distribution of the Clusters

\section{CONCLUSION}

The challenge of identifying effective segmentation strategies has led researchers to adopt a variety of approaches including usage rates for various financial services, demographics, and product purchase decisions (McDougall and Levesque, 1994). In this study, consumers' environmentally sensitive purchase behaviour was assumed to be influenced positively by their environmental concerns, but negatively by their scepticisms. In the first stage of the research, this assumption was confirmed by a regression analysis while in the second stage consumers were clustered by their level of environmental concerns and scepticisms about the environmental claims.

Cluster analysis results have indicated that consumers can be grouped in three market segments according to their environmental concerns and scepticisms. 1) Consumers who have high level of environmental concerns, but are very sceptical about the environmental claims (keen sceptics) can feel uncomfortable because of the exaggerated claims even though they purchase environmentally friendly (green) products. Therefore, companies should try to relieve these customers by clearing their minds and make them believe to their claims in the advertisements; 2) consumers who have average level of environmental concerns and scepticisms (hesitants) either do not attempt to purchase these kind of products or feel irresponsible about the environmental issues. These consumers are not expected to purchase environmentally friendly products in a regular basis or show any environmentally sensitive consumer action; and 3) consumers who have high level of environmental concerns and low level of scepticisms (fanatics) may insist on purchasing environmentally friendly (green) products as they think their purchase approaches can help solving the environmental problems of the world. In summary, this study showed that marketing managers of companies should recognize the existence of different market segments in terms of environmental concerns and they should identify these needs and expectations if they want to gain competitive advantage in the global marketplace. Environmentally sensitive market segments have their own characteristics and can be negatively influenced by exaggerated claims in the advertisements.

\section{REFERENCES}

[1] S.Bamberg. How does environmental concern influence specific environmentally related behaviours? A new answer to an old question. Journal of Environmental Psychology 2003, 23: 21-32.

[2] R. Y.K.Chan, L.B.Y. Lau. The effectiveness of environmental claims among Chinese consumers: influences of claim type, country disposition and ecocentric orientation. Journal of Marketing Management 2004, 20: 273-319.

[3] L.A.Crosby, J.D.Gill, J.R.Taylor. Consumer/voter behaviour in the passage of the Michigan container law. Journal of Marketing 1981, 45(2), 19-32

[4] R.E.Dunlap, R.E. Jones. Environmental Concern: Conceptual and Measurement Issues. In: R.E.Dunlap and W.Michelson (eds.). Handbook of Environmental Sociology Westport, CN: Greenwood Press. 2002.pp.482-524.

[5] P.S.Ellen, J.L.Wiener, C. Cobb-Walgren. The role of perceived consumer effectiveness in motivating environmentally conscious behaviours. Journal of Public Policy \& Marketing 1991, 10(2): 102-117

[6] J.D.Gill, L.A.Crosby, J.R.Taylor. Ecological concern, attitudes, and social norms in voting behaviour. Public Opinion Quarterly 1986, 50(4): 537-554.

[7] Y.Kim, S.M.Choi. Antecedents of green purchase behaviour: an examination of collectivism, environmental concern, and PCE. Advances in Consumer Research 2005, 32:592-599.

[8] T.Mainieri, E.G.Barnett, T.R.Valdero, J.B.Unipan, S.Oskamp. Green buying: the influence of environmental concern on consumer behaviour. The Journal of Social Psychology 1997, 137(2), 189-204

[9] A.M.D.Martin, V. Iglesias, R.Vazquez, A.V.Ruiz. The use of quality expectations to segment a service market. Journal of Services Marketing 2000, 14(2): 132-146 
[10] G.H.G.McDougall, T.J. Levesque. Benefit segmentation using service quality dimensions: an investigation in retail banking. International Journal of Bank Marketing 1994, 12 (2):15-23.

[11] L.A.Mohr, D.Eroğlu, P.S.Ellen. The development and testing of a measure of skepticism toward environmental claims in marketers' communications. The Journal of Consumer Affairs 1998, 32(1): 30-55.

[12] C.Obermiller, E.R.Spangenberg. Development of a scale to measure consumer scepticism toward advertising. Journal of Consumer Psychology 1998, 7(2): 159-186.

[13] C.Obermiller, E.R.Spangenberg, D. Maclachlan. Ad skepticism: the consequences of disbelief. Journal of Advertising 2005, 34(3):7-17.

[14] B.B.Schlegelmilch, G.M.Bohlen, A.Diamantopoulos. The link between green purchasing decisions and measures of environmental consciousness. European Journal of Marketing 1996, 30(5): 35-55.

[15] P.C. Stern, T.Dietz. The value basis of environmental concern. Journal of Social Issues 1994, 50(3): 65-84 